\title{
THE ARGUMENT AGAINST INFLATION FROM GOVERNMENT LOANS
}

\author{
By Alexander D. Noyes, \\ Financial Editor, New York Evening Post.
}

After Professor Hollander's comprehensive statement of the economic theory bearing on this question, and Mr. Miller's thorough review of the general principles involved, I feel as if further comment would be superfluous. What I shall endeavor to do, however, in this article, is to direct attention particularly to the plain and practical aspects of the question in the light of experience.

The broad field over which Mr. Miller's article carries us diverts attention from the actual subject-which is not, Are we in danger of inflation? but, Do government loans cause inflation? It is not enough to say that there is inflation and that there are government loans, and that therefore the loans may have caused the inflation. Even accepting Mr. Miller's facts and figures regarding inflation of bank credit, we must still inquire where and how that inflation occurred, and what its precise relation is both to the government loans and to what we ordinarily accept as the economic consequences of what we call inflation.

But the question, Do government loans cause inflation? is one of those questions in which the dispute is apt to hang upon definitions. What do we mean by inflation? If we mean inflation of the currency, then the answer is that government loans may cause inflation, but that it can happen only through the use of special machinery whereby paper currency is deliberately put out on the security of the government bonds. This has occurred during the present war in the case of Russia, whose state bank, which issues the paper currency of the nation, has increased its note circulation $\$ 7,500,000,000$ since the war began, while increasing its holdings of Russian government bonds by $\$ 5,600,000,000$ and not increasing its gold reserve at all. It is so in a less degree in the case of France, where the Bank of France reports $\$ 2,400,000,000$ advances to the government for war purposes and $\$ 600,000,000$ for loans to the allies of France; against which obligations there has been an in135 
crease of $\$ 3,000,000,000$ in the note circulation of the bank with no proportionate increase in its gold reserve.

It is difficult to say how far the increase of two thousand million dollars or so in note issues of the German State Bank is connected with loans on government bonds; but there is no doubt of that connection in the case of the German loan bureaus, which have issued $\$ 1,500,000,000$ currency, unsecured by a gold reserve, on all sorts of collateral. The process was at work in a degree during our Civil War, when note issues of the national banks were permitted only on the security of United States government bonds, and when $\$ 236,000,000$ of such newly issued bonds were acquired in war time for that purpose. But it will be observed that this is only a possible result of the policy of government loans, not a necessary one. It cannot be said that it is an inherent effect of such loans. It is not in any respect a probable direct result of our own war loans.

If by "inflation" we mean expansion of credit, then again the issue of government loans might have that effect, or it might not. Very large issues of new securities, whether by governments or corporations, will usually cause a large increase in the loan account of banks. Individual subscribers, when the loan is especially attractive or when (as nowadays) the motive of patriotism is invoked to increase the subscriptions, are apt to borrow from their banks money to pay their subscriptions. Most of them will expect to pay back such loans from their future accruing income. But the bank loans may be made permanent for the period of war or longer. In Germany they are explicitly made so.

But what most people mean when they talk of "inflation" is a third possible result-the abnormal raising of prices for commodities. It was undoubtedly this kind of inflation, as a consequence of large war loan issues, which President Wilson had in mind in his remarks on the subject in his war speech to Congress on April 2. He then said, regarding the financing of the war:

It will involve of course the granting of adequate credits to the governmentsustained, I hope, so far as they can equitably be sustained by the present generation, by well conceived taxation.

I say sustained so far as may be equitable by taxation, because it seems to me that it would be most unwise to base the credits, which will now be necessary, entirely on money borrowed. It is our duty, I most respectfully urge, to protect our people, so far as we may, against the very serious hardships and evils which would be likely to arise out of the inflation which would be produced by vast loans. 
This clearly has reference to inflation of prices. Let us see how the issue of war loans, taken by itself, would have that effect. We know from all economic experience that sudden and large increase of a paper currency irredeemable in gold will drive up prices. It will do so because prices will be quoted in that currency, and, since in due course the paper currency itself will be worth less than its face value in gold, "paper prices" will necessarily be higher than the previous "gold prices." In so far, therefore, as new government loans are made the basis for paper currency issues and that currency is not redeemed on demand in gold, the government loan policy will undoubtedly inflate prices.

But prices are sometimes driven up also through the mere fact of expanded bank credits. When every producer, middleman, or retailer, can get and does get on easy terms abundant credit at his bank, he will be in no hurry to sell. If he chooses, he may hold for higher prices, and the fact that demand is apt to be increased all along the line because easy access to bank credit will facilitate the paying of such prices by middleman, retailer and consumer. This explains the well known fact that rising bank reserves, easy money and constantly expanding bank loans, are an invariable accompaniment of what we call "good times," and that they figure both as cause and consequence of the rising prices which then prevail.

But is this the case with a bank loan expansion caused, directly or indirectly, by subscriptions to large government loans? That is the real question, and I cannot agree with what I understand to be Mr. Miller's position regarding it. Inflation of bank loans there may be, and inflation of prices there may be; but what we have to determine is, whether the government's bond issues caused both. I think the answer must be in the negative. When banks are compelled to expand their loans very heavily in order to facilitate subscription to the government bonds, there will be less, not more, left in their legitimate credit fund to apply to ordinary commercial loans.

It is perfectly true that such a situation may be modified, through deliberate action of the banks, through special facilities offered by the reserve banks in rediscounting loans secured by the new war bonds or through other causes. But we are talking now of the actual effect of the war loan issue itself. In that regard it ap- 
pears to me that the ordinary credit facilities of the banks, which might be utilized to hold up prices in the commercial markets, will not be increased by the government bond issue, and that they may be very considerably decreased.

Such new credits as are obtained by subscribers to a war loan are spent in the subscription, and they are therefore evidently not available for any commercial purposes. No doubt the war bonds may themselves be used under the law to create new bank reserves through rediscount of loans secured by such bonds. But exactly the same thing may be accomplished through rediscounting of loans secured by commercial paper; and since the requirement of cash reserves in the federal banks fixes a limit to the aggregate rediscounts, it follows that the more of them a bank makes on the basis of loans secured by war bonds, the less it can make on the basis of loans secured by merchants' notes.

As to whether the rise of prices incident to any prolonged war would not be greater if the war is financed by government loans than if the war is financed by taxes, that is another question. Imagining that the present war, for instance, were financed solely by taxes, bearing heavily on every individual, the rise in prices would unquestionably be less than it has been. But that would be so, chiefly if not wholly because the weight of taxation would have made the average citizen able to buy very much less of the ordinary necessities than he had bought before. This, however, is something like begging the question, for the man whose means of buying necessities is cut off will scarcely be in a better position than the man who, with an unchanged income, has to pay more for them. If, as is the case in our present scheme of war taxation, most of it is raised by heavy exactions from very rich individuals, reduced personal expenditure may not result at all. A 60 per cent tax on a million dollar income will not compel that taxpayer to curtail his purchases of necessities. The public mind is sometimes apt to lay stress on the fact that proceeds of these huge loans are used in buying food and material on an unprecedented scale, and that therefore the loans cause the resultant high prices. But it is the government's purchases, not its borrowings, which act directly on prices of commodities, and since the war material must be had, in one way if not in another, the government demands would equally affect supplies and prices if the material were purchased wholly out of the proceeds of taxation. 
The sum of the matter is then, that government loans, especially when issued in the present prodigious amounts, may cause inflation of the currency, but will not do so unless both the machinery to facilitate it and the disposition to undertake it are in evidence; that government loans will probably result in increase of bank loans to subscribers; but that the increase in bank loans for that purpose will of itself have no effect in the way of inflating prices, and might, through absorbing part of the credit fund usually reserved for commercial borrowers, act indirectly as a check to rising prices. The primary cause of the present high war-time prices is the enormous demands of governments in connection with the war, along with the impairment or blockade of many ordinary sources of supply. The secondary cause is the currency inflation and currency depreciation in Europe, which have indirectly affected prices (partly through shipment of gold from the depreciated currency markets) even in countries whose currency is not depreciated. That the government loans, except as they have been deliberately used as a basis for currency inflation, have in themselves been a cause for the rise in prices, I believe cannot be proved. 